27. Pick E, Keisari Y 1980 A simple colorimetric method for the measurement of hydrogen peroxide produced by cells in culture. J Immunol 38:161-170

28. Glantz SA 1981 Primer of Biostatistics. McGraw-Hill, New York, pp 87-89

29. Mandell GL, Novik WJ 1988 Proceedings of a Symposium, Pentoxifylline and Leukocyte Function. Hoechst-Roussel Pharm, Inc, Sommerville, NJ

30. Ehrly AM 1976 Improvement of the flow properties of blood. Angiology 27:188-196

31. Ward A, Clissold SP 1987 Pentoxifylline: a review of its pharmacodynamic and pharmacokinetic properties and its therapeutic efficacy. Drugs 34:5097

32. Smith RV, Waller ES, Doluisio JT, Bauza MT, Puri SK, Ho I, Lassman HB 1986 Pharmacokinetics of orally administered pentoxifylline in humans. J Pharm Sci 75:47-52

33. Sullivan GW, Carper HT, Novick WJ, Mandell GL 1988 Inhibition of the inflammatory action of interleukin- 1 and tumor necrosis factor (alpha) on neutrophil function by pentoxifylline. Infect Immun 56:1722-1729

34. Hammerschmidt DE, Kotasek D, McCarthy $T$, Huh P, Freyburger G, Vercellotti GM 1988 Pentoxifylline inhibits granulocyte and platelet function, including granulocyte priming by platelet activating factor. J Lab Clin Med $112: 254-263$

35. Merritt TA, Cochrane CG, Holcomb K, Bohl B, Hallman M, Strayer D, Edwards DK, Gluck L 1983 Elastase and alpha 1-proteinase inhibitor activity in tracheal aspirates during respiratory distress syndrome. Role of inflammation in the pathogenesis of bronchopulmonary dysplasia. J Clin Invest 72:656-666

36. Ogden BE, Murphy S, Saunders GC, Johnson JD 1983 Lung lavage of newborns with respiratory distress syndrome. Prolonged neutrophil influx is associated with bronchopulmonary dysplasia. Chest 83:31S-33S

37. Eisenfeld L, Krause PJ, Herson V, Savidakis J, Bannon P, Maderazo E, Woronick C, Giuliano C, Banco L 1990 A longitudinal study of neutrophil adherence and motility. J Pediatr 117:926-929

38. Miller ME 1975 Developmental maturation of human neutrophil motility and its relationship to membrane deformability. In: Bellanti JA, Dayton DH (eds) The Phagocytic Cell in Host Resistance. Raven Press, New York, pp 295-307

39. Strauss RG, Hart MG 1981 Spontaneous and drug-induced concanavalin A capping of neutrophils from human infants and their mothers. Pediatr Res 15:1314-1318

40. Yasui K, Masuda M, Matsuoka T, Yamazaki M, Komiyama A, Akabane T, Hasui M, Kobayashi Y, Murata K 1988 Abnormal membrane fluidity as a cause of impaired functional dynamics of chemoattractant receptors on neonatal polymorphonuclear leukocytes: lack of modulation of the receptors by a membrane fluidizer. Pediatr Res 24:442-446

41. Hilmo A, Howard T 1987 F-actin content of neonate and adult neutrophils Blood 69:945-949

42. Sacchi F, Augustine NH, Coello MM, Morris EZ, Hill HR 1987 Abnormality in actin polymerization associated with defective chemotaxis in neutrophils from neonates. Intl Arch Allergy Appl Immunol 84:32-39

43. Rao KMK, Crawford J, Currie MS, Cohen HJ 1988 Actin depolymerization and inhibition of capping induced by pentoxifylline in human lymphocytes and neutrophils. J Cell Physiol 137:577-582

44. Needham D, Armstrong M, Hatchell DL, Nunn RS 1989 Rapid deformation of "passive" polymorphonuclear leukocytes: the effects of pentoxifylline. J Cell Physiol 140:549-557

\title{
Announcement
}

\section{Call for Abstracts}

The Society for Behavioral Pediatrics will conduct its 9th Annual Scientific Meeting on September 22-23, 1991 at the Omni Inner Harbor Hotel in Baltimore, MD. We invite you to submit abstracts of research papers for consideration for presentation at the scientific sessions. Abstracts must be received by March 1, 1991. For further information and abstract forms, please contact Ms. Noreen Spota at (215) 248-9168. 